\title{
ВИКОНКОМИ В СИСТЕМІ МІСЦЕВОГО САМОВРЯДУВАННЯ - НЕОБХІДНІСТЬ ЧИ АТАВІЗМ?
}

\begin{abstract}
У статті здійснено аналіз доцільності збереження в системі органів місцевого самоврядування виконавчих комітетів рад як колегіальних органів. Однак перегляд доцільності існування деяких з них як виконавчих комітетів місиевих рад - $е$ нагальною проблемою. Зазначено, шзо на сьогодні відсутні спеціальні комплексні дослідження, які розкривають порядок функиіонування цих органів. Існує потреба чіткого з'ясування місия, ролі та значення виконавчих органів у системі державного управління, щзо зумовило вибір теми та напряму дослідження представленої статті. Загальна проблема - подолання перешкод у процесі створення умов для підготовки та прийняття ефективних управлінських рішень. Розглянуті та проаналізовані згідно із Законом Украӥни «Про місчеве самоврядування в Украӥні» повноваження виконавчих органів місцевих рад. На підставі проведеного аналізу можна констатувати, щзо виконавчий комітет, займаючи центральне місце в системі виконавчих органів місцевої ради, в той же час є особливим органом колегіального вирішення питань, щзо віднесені до його компетениії. Коли була у 1936 роичі прийнята сталінська Конституиія СРСР усі ради отримали статус органів місцевого самоврядування, однак фактичне управління на рівні територіальних громад в Украӥні здійснювали місцеві партійні організації. Було зазначено, щзо останню роль в иій системі проголоменого самоврядування жорстко обмеженого партійним контролем, відігравали саме виконавчі комітети рад, до складу яких входили переважно місиева партійна номенклатура.

Природа виконавчого комітету як інструменту виконання рішень місцевих рад докорінно змінилася. Прискіпливе дослідження структури органів місчевого самоврядування в європейських крайнах дозволяє стверджувати, щзо практично усі європейські крайни мають один колегіальний орган - раду депутатів. У статті зазначено, щзо виконавчий комітет виконує сьогодні усі ті функиії, які виконують постійні комісії ради і навіть значно ширші. Вивчення положень та регламентів виконавчих комітетів Луцької, Криворізької, Львівської міських рад дозволяє стверджувати, шчо більщість таких місиевих нормативних актів трактує виконком як виконавчий орган міської ради, хоча насправді він таким не є. Аналіз повноважень місиевих рад та виконавчих комітетів циих рад дозволяє стверджувати, щчо обсяг повноважень виконавчого комітету є ширшим, ніж повноваження ради.

Ключові слова: виконавчі комітети місиевих рад, повноваження органів місцевого самоврядування, повноваження виконавчого комітету ради, повноваження сільських, селищних, міських рад.
\end{abstract}

Л.П. ОЛЕНКОВСКАЯ

Херсонский национальный технический университет ORCID: 0000-0002-8417-3827

О. В. ПРОНИНА

Херсонский национальний технический університет ORCID: /0000-0002-4894-1825

\section{ИСПОЛКОМ В СИСТЕМЕ МЕСТНОГО САМОУПРАВЛЕНИЯ -НЕОБХОДИМОСТЬ ИЛИ АТАВИЗМ?}

В статье проведен анализ целесообразности сохранения в системе органов местного самоуправления исполнительных комитетов советов как коллегиальных органов. Однако просмотр целесообразности существования некоторых из них - как исполнительных комитетов местных советов - является насущной проблемой. Отмечено, что сегодня отсутствуют специильнье комплексные исследования, которые раскрывают порядок функиионирования этих органов. Существует потребность четкого выяснения места, роли и значения исполнительных органов в системе государственного управления, что обусловило выбор темы и направления исследования представленной статье. Общая проблема - преодоление препятствий в процессе создания условий для подготовки и принятия эффективных управленческих решений. Рассмотрены и проанализировань в соответствии с Законом Украинь «О местном самоуправлении в Украине» полномочия исполнительньх органов местных советов. На основании проведенного анализа можно констатировать, что исполнительный 
комитет, занимая центральное место в системе исполнительных органов местного совета, в то же время является органом коллегиального решения вопросов, отнесенных к его компетеничи. Когда была в 1936 году принята сталинская Конституция СССР все советы получили статус органов местного самоуправления, однако фактическое управление на уровне территориальных общин в Украине осуществляли местные партийные организачии. Было отмечено, что последнюю роль в этой системе провозглашенного самоуправления жестко ограниченного партийным контролем, играли именно исполнительные комитеты советов, в состав которых входили преимущественно местная партийная номенклатура.

Природа исполнительного комитета как инструмента выполнения решений местных советов 8 корне изменилась. Тщзательное исследование структуры органов местного самоуправления $в$ европейских странах позволяет утверждать, что практически все европейские страны имеют один коллегиальный орган - совет депутатов. В статье указано, что исполнительный комитет выполняет сегодня все те функции, которые выполняют постоянные комиссии совета и даже значительно шире. Изучение положений и регламентов исполнительных комитетов Луикого, Криворожской, Львовской городских советов позволяет утверждать, что больиинство таких местных нормативных актов трактует исполком как исполнительный орган городского совета, хотя на самом деле он таковым не является. Анализ полномочий местных советов и исполнительных комитетов этих советов позволяет утверждать, что объем полномочий исполнительного комитета шире, чем полномочия совета.

Ключевые слова: исполнительные комитеты местных советов, полномочия органов местного самоуправления, полномочия исполнительного комитета совета, полномочия сельских, поселковых советов.

L.P. OLENKOVSKAY

Kherson Nachional Technical University ORCID: 0000-0002-8417-3827

O.V. PRONINA

Kherson Nachional Technical University

ORCID: 0000-0002-4894-1825

\section{EXECUTIVE COMMITTEES IN THE SYSTEM OF LOCAL GOVERNMENT - NECESSITY OR ATAVISM}

The article analyzes the feasibility of maintaining the executive committees of councils as collegial bodies in the system of local self-government bodies. However, reviewing the appropriateness of some of them - as executive committees of local councils - is an urgent problem. It is noted that today there are no special comprehensive studies that reveal the functioning of these bodies. There is a need to clearly clarify the place, role and significance of the executive bodies in the system of public administration, which led to the choice of topic and direction of research in this article. The general problem is overcoming obstacles in the process of creating conditions for the preparation and adoption of effective management decisions. The powers of the executive bodies of local councils were considered and analyzed in accordance with the Law of Ukraine "On Local Self-Government in Ukraine". Based on the analysis, it can be stated that the executive committee, occupying a central place in the system of executive bodies of the local council, at the same time is a body for the collegial decision of issues within its competence. When the Stalinist Constitution of the USSR was adopted in 1936, all councils received the status of local self-government bodies, but the actual management at the level of territorial communities in Ukraine was carried out by local party organizations. It was noted that the last role in this system of proclaimed self-government, which was strictly limited by party control, was played by the executive committees of the councils, which consisted mainly of the local party nomenklatura.

The nature of the executive committee as a tool for implementing the decisions of local councils has changed radically. A careful study of the structure of local governments in European countries suggests that almost all European countries have one collegial body - the Council of Deputies. The article states that the executive committee performs today all the functions that are performed by the standing commissions of the council and even much wider. A study of the provisions and regulations of the executive committees of Lutsk, Kryvyi Rih, and Lviv city councils suggests that most such local regulations are interpreted by the executive committee as the executive body of the city council, although in reality it is not. An analysis of the powers of local councils and the executive committees of these councils suggests that the scope of powers of the executive committee is broader than the powers of the council.

Key words: executive committees of local councils, powers of local self-government bodies, powers of the executive committee of the council. Powers of village, settlement, city councils.

\section{Постановка проблеми}

Є явища, інституції в системі управління, функціональність яких начебто не викликає сумніву. Однак перегляд доцільності існування деяких з них - як виконавчих комітетів місцевих рад - 
нагальною проблемою. Адже світ стає на стільки динамічним, що наявність двох колегіальних органів в системі місцевого самоврядування - виконавчого комітету та ради - сповільнює процес прийняття управлінських рішень. Дослідження ефективності застосування такого управлінського інструменту не проводилося ніколи.

Загальна проблема - подолання перешкод у процесі створення умов для підготовки та прийняття ефективних управлінських рішень. А це неможливо без аналізу доцільності функціонування кожної складовою системи прийняття та реалізації рішень.

\section{Аналіз останніх досліджень і публікацій}

Динамічне сьогодення вимагає від органів місцевого самоврядування зважених, однак дуже енергійних темпів прийняття управлінських рішень. А отже максимального скорочення часу, який витрачається на процедури, пов'язані із їх ухваленням. А удосконалення функціонування виконавчих органів місцевих рад та їх взаємодії з депутатським корпусом дозволяє сформулювати гіпотезу щодо досліджень і публікацій. Питаннями діяльності виконавчих органів місцевих рад займаються такі вчені як В. Авер'янова, М. Корнієнко, В. Кравченко, В. Куйбіда, П. Любченко, М. Пітцик, В. Погорілко, К. Соляннік, Ю. Тодик, В. Шумілкін, О. Фрицький та ін.

Проте в сучасній науці проблеми діяльності виконавчих органів місцевих рад ще не отримали належного висвітлення. Відсутні спеціальні комплексні дослідження, які розкривають порядок функціонування цих органів. Існує потреба чіткого з'ясування місця, ролі та значення виконавчих органів у системі державного управління, що зумовило вибір теми та напряму дослідження представленої статті. Слід зазначити, що останнім часом науковці уникали розгляду цього питання.

\section{Формулювання мети дослідження}

Метою публікації є висвітлення історії виникнення та функці-онування виконавчих комітетів місцевих рад, дослідження та співставлення повноважень колегіальних органів влади в системі місцевого самоврядування.

\section{Викладення основного матеріалу дослідження}

Викона́вчий о́рган місце́вого самоврядува́ння - створюваний представницьким органом місцевого самоврядування орган, що є підконтрольним і підзвітним відповідній раді, а 3 питань здійснення делегованих йому повноважень органів виконавчої влади — також підконтрольним відповідному органу виконавчої влади.

Виконавчими органами сільських, селищних, міських, районних у містах (у разі їх створення) рад в Україні є їх виконавчі комітети, відділи, управління та інші створювані радами виконавчі органи.

Виконавчий комітет ради утворюється відповідною радою на строк іiі повноважень у складі відповідно сільського, селищного, міського голови, районної в місті ради — голови відповідної ради, заступника (заступників) сільського, селищного, міського голови з питань діяльності виконавчих органів ради, керуючого справами (секретаря) виконавчого комітету, а також керівників відділів, управлінь та інших виконавчих органів ради, інших осіб. До складу виконавчого комітету сільської, селищної, міської ради входить також за посадою секретар відповідної ради.

Для того, щоб визначити роль і місце виконавчих органів місцевих рад у системі державного управління, слід в першу чергу наголосити на тому, що виконавчі органи реалізують свої функції на місцевому рівні і є одним із інструментів реалізації місцевого самоврядування в Україні. Конституція України у ст. 140 говорить, що місцеве самоврядування здійснюється територіальною громадою як безпосередньо, так і через органи місцевого самоврядування: сільські, селищні, міські ради та їх виконавчі органи.

Таким чином, виконавчі органи є одним 3 елементів в системі місцевого самоврядування, взаємовідносини якого 3 іншими елементам цієї системи визначають іiі основні характеристики, як цілісної і самодостатньої. А так як місцеве самоврядування являє собою можливість, право територіальної громади самостійно вирішувати економічні, соціальні, політичні питання місцевого характеру, то є підстави говорити про нього як про засіб здійснення державою управлінських функцій на місцевому рівні через свої представництва.

Відповідно до ст. 52 Закону, виконавчий комітет сільської, селищної, міської, районної в місті ради може розглядати і вирішувати питання, віднесені Законом до відання виконавчих органів місцевих рад. Виключно виконавчому комітету належить:

а) попередній розгляд проектів місцевих програм соціально-економічного і культурного розвитку, цільових програм з інших питань, місцевого бюджету, проекти рішень 3 інших питань, що вносяться на розгляд відповідної ради;

б) координація діяльності відділів, управлінь та інших виконавчих органів ради, підприємств, установ, організацій, що належать до комунальної власності територіальної громади, заслуховування звітів про роботу їх керівників;

в) зміна або скасування актів підпорядкованих йому відділів, управлінь, інших виконавчих органів ради, а також їх посадових осіб. 
Таким чином, виконавчий комітет, займаючи центральне місце в системі виконавчих органів місцевої ради, в той же час є особливим органом колегіального вирішення питань, що віднесені до його компетенції.

3 прийняттям 5 грудня 1936 року сталінської Конституції СРСР усі ради отримали статус органів місцевого самоврядування, однак фактичне управління на рівні територіальних громад в Україні здійснювали місцеві партійні органи під керівництвом центральних органів КП(б)У та ВКП(б). I не останню роль в цій системі проголошеного самоврядування жорстко обмеженого партійним контролем, відігравали саме виконавчі комітети рад, до складу яких входили переважно місцева партійна номенклатура, керівники важливих підприємств, які також за замовчуванням були членами Комуністичної партії. Усе виглядало логічно: місцеві ради, які діяли (і продовжують діяти) на громадських засадах та на свої засідання збираються відповідно до регламенту, необхідний інструмент реалізації рішень таких рад. На етапі становлення місцевих рад як органів місцевого самоврядування виконавчі комітети ради утворювалися як органи, що контролювали діяльність виконавчих органів ради.

Так формувалася ілюзія народовладдя. А реального управління селами, селищами містами директорами підприємств, головами колгоспів, партійними функціонерами.

Традиція закріпилася, і незначно трансформуючись, проіснувала до теперішнього часу. Виконавчі комітети, які також діяли і діють на громадських засадах , почали утворювати відділи, а потім більш складні інституції, набувати формату постійно діючих установ, які також мали назву «Виконавчий комітет».

Тож виконавчий комітет як сукупність структурних підрозділів, діяльність яких спрямована на виконання рішень ради і виконавчий комітет як колегіальний орган, тривалий час існують паралельно.

Як повноваження місцевих рад, так і структура, яка забезпечує їх виконання, поступово ускладнювалася. Самі ради із зібрань активних громадян поступово перетворилися в органи прийняття управлінських рішень. Виконавчі комітети трансформувалися у виконавчі органи місцевих рад, що було закріплено законодавчо у Законі України «Про місцеве самоврядування в Україні» [1].

А природа виконавчого комітету як інструменту виконання рішень місцевих рад докорінно змінилася. Він перетворився на іще один колегіальний орган в системі місцевого самоврядування. Прискіпливе дослідження структури органів місцевого самоврядування в європейських країнах дозволяє стверджувати, що практично усі європейські країни мають один колегіальний орган - раду депутатів.

Слід зазначити, що виконавчий комітет виконує сьогодні усі ті функції, які виконують постійні комісії ради і навіть значно ширші. Вивчення положень та регламентів виконавчих комітетів Луцької, Криворізької, Львівської міських рад дозволяє стверджувати, що більшість таких місцевих нормативних актів трактує виконком як виконавчий орган міської ради, хоча насправді він таким не є.

Наприклад, регламент роботи виконавчого комітету Луцької міської ради[2] містить розділ 2.4., який окреслює коло повноважень виконавчого комітету, а саме: він

- $\quad$ розглядає і вирішує питання, віднесені Законом України «Про місцеве самоврядування в Україні»[1] до відання виконавчих органів ради, в межах своїх повноважень ухвалює рішення, обов'язкові для виконання всіма розташованими на території міста підприємствами, установами, організаціями, посадовцями і мешканцями міста;

- попередньо розглядає та схвалює проекти міських програм соціально-економічного і культурного розвитку, цільових програм з інших питань, прогноз міського бюджету, проект міського бюджету, проекти рішень з інших питань, що вносяться на розгляд міської ради;

- координує діяльність виконавчих органів міської ради, підприємств, установ, організацій, що належать до комунальної власності територіальної громади міста, заслуховує звіти про роботу їх керівників;

- організовує виконання рішень міської ради, а також затверджених міською радою планів та програм економічного і соціального розвитку, бюджету, - відповідно до норм Закону України « Про місцеве самоврядування»

- Регламент Львівської міської ради носить більш функціональний характер і взагалі за дужками залишає причини існування і повноваження Виконавчого комітету Львівської міської ради. Він докладно описує порядок роботи, прийняття рішень, порядок легітимізації рішень.

Як бачимо, практично усі функції міської ради дублюються виконавчим комітетом. А ті, які є унікальними, можуть виконуватися представницькими органами місцевого самоврядування.

Аналіз повноважень місцевих рад та виконавчих комітетів цих рад дозволяє стверджувати, що обсяг повноважень виконавчого комітету є ширшим, ніж повноваження ради 
Співставлення повноважень місцевих рад та виконавчих комітетів рад.

\begin{tabular}{l}
\hline \multicolumn{4}{|c}{ Рада громади } \\
\hline Стаття 25. Загальна компетенція сільських, селищних, \\
міських рад \\
5) затвердження за пропозицією сільського, селищного, \\
міського голови структури виконавчих органів ради, \\
загальної чисельності апарату ради та їі виконавчих \\
органів відповідно до типових штатів, затверджених \\
Кабінетом Міністрів України, витрат на їх утримання;
\end{tabular}

Стаття 26. Виключна компетенція сільських, селищних, міських рад

22) затвердження програм соціально-економічного та культурного розвитку відповідних адміністративнотериторіальних одиниць, цільових програм 3 інших питань місцевого самоврядування;

23) розгляд прогнозу місцевого бюджету, затвердження місцевого бюджету, внесення змін до нього; затвердження звіту про виконання відповідного бюджету;

24) встановлення місцевих податків і зборів відповідно до Податкового кодексу України;

25) утворення цільових фондів, затвердження положень про ці фонди;

26) прийняття рішень щодо здійснення місцевих запозичень;

6) утворення за поданням сільського, селищного, міського голови інших виконавчих органів ради;

7) прийняття рішень щодо передачі коштів 3 відповідного місцевого бюджету;

28) прийняття рішень щодо надання відповідно до чинного законодавства пільг по місцевих податках i зборах, а також земельному податку;

29) встановлення для підприємств, установ та організацій, що належать до комунальної власності відповідних територіальних громад, розміру частки прибутку, яка підлягає зарахуванню до місцевого бюджету;

30) прийняття рішень щодо відчуження відповідно до закону комунального майна; затвердження місцевих програм приватизації, а також переліку об'єктів комунальної власності, які не підлягають приватизації; визначення доцільності, порядку та умов приватизації об'єктів права комунальної власності; вирішення питань про придбання в установленому законом порядку приватизованого майна, про включення до об'єктів комунальної власності майна, відчуженого у процесі приватизації, договір купівлі-продажу якого в установленому порядку розірвано або визнано недійсним, прийняття рішення про здійснення державно-приватного партнерства щодо об’єктів комунальної власності, у тому числі на умовах концесії, про створення, ліквідацію, реорганізацію та перепрофілювання підприємств, установ та організацій комунальної власності відповідної територіальної громади.

Реорганізація або ліквідація навчальних закладів комунальної форми власності здійснюється за рішенням місцевої ради;

41) прийняття рішень 3 питань адміністративнотериторіального устрою в межах і порядку, визначених цим та іншими законами;
Виконавчий комітет ради громади

Виконавчий комітет сільської,
селищної, міської, районної у місті (у разі iii створення) ради може розглядати i вирішувати питання, віднесені цим Законом до відання виконавчих органів ради.

2. Виконавчий комітет ради:

1) попередньо розглядає та схвалює проекти місцевих програм соціальноекономічного i культурного розвитку, цільових програм 3 інших питань, прогноз місцевого бюджету, проект місцевого бюджету, проекти рішень 3 інших питань, що вносяться на розгляд відповідної ради;

2) координує діяльність відділів, управлінь та інших виконавчих органів ради, підприємств, установ та організацій, що належать до комунальної власності відповідної територіальної громади, заслуховує звіти про роботу їх керівників;

3) має право змінювати або скасовувати акти підпорядкованих йому відділів, управлінь, інших виконавчих органів ради, а також їх посадових осіб.

3. Сільська, селищна, міська рада може прийняти рішення про розмежування повноважень між іiі виконавчим комітетом, відділами, управліннями, іншими виконавчими органами ради та сільським, селищним, міським головою (у тому числі з метою забезпечення надання адміністративних послуг у строк, визначений законом) в межах повноважень, наданих цим Законом виконавчим органам сільських, селищних, міських рад. 
встановлення відповідно до законодавства правил 3 питань благоустрою території населеного пункту, забезпечення в ньому чистоти і порядку, торгівлі на ринках, додержання тиші в громадських місцях, за порушення яких передбачено адміністративну відповідальність

21) прийняття рішень про об'єднання в асоціації або вступ до асоціацій, інших форм добровільних об'єднань органів місцевого самоврядування та про вихід з них;

$21^{-\mathbf{1}}$ ) схвалення угод про об'єднання єврорегіонального співробітництва, прийняття рішень про утворення об'єднання єврорегіонального співробітництва, про приєднання до такого об'єднання або про вихід 3 нього, затвердження статуту об'єднання єврорегіонального співробітництва та внесення до нього змін;

$21^{-2}$ ) прийняття рішень про вступ до європейського об'єднання територіального співробітництва та про вихід 3 такого об'єднання;

Здавалося, таблиця 1, в якій представлено аналіз обсягів повноважень місцевої ради та виконавчого комітету, наочно демонструє значно більший обсяг повноважень ради. Однак, користуючись своїм правом розмежування повноважень між виконавчими органами, (ст 52, п 3 Закону України «Про місцеве самоврядування в Україні») ради, як правило, значно розширюють обсяг їх повноважень через положення про виконавчий комітет ради. Так, в положенні про виконавчий комітет Криворізької міської ради бачимо коло повноважень, які повністю повторюють повноваження міської ради - у сфері соціально-економічного й культурного розвитку, планування та обліку; у галузі бюджету, фінансів і цін; участі в здійсненні державної регуляторної політики в межах та в спосіб, установлені Законом України «Про засади державної регуляторної політики у сфері господарської діяльності»; організаційного забезпечення надання адміністративних послуг органів виконавчої влади через Центр надання адміністративних послуг «Муніципальний центр послуг м. Кривого Рогу»; управління комунальною власністю; у галузі житлово-комунального господарства, побутового, торговельного обслуговування, громадського харчування, транспорту та зв'язку; та інш.

Положення окреслює скоріше сфери, в яких виконавчий комітет має повноваження, не уточнюючи їх меж. Крім того, пункт 2.6. згаданого Регламенту передбачає, що «Виконавчий комітет міської ради, крім повноважень, передбачених Законом України «Про місцеве самоврядування в Україні», здійснює й інші повноваження, передбачені вимогами чинного законодавства України, рішеннями міської ради».

Своїми рішеннями місцеві ради перетворили виконавчі комітети на складні утворення, які

а) мають самоврядні повноваження, а отже, є органом місцевого самоврядування;

б) мають делеговані повноваження через процедуру розмежування повноважень місцевою радою i $\epsilon$ виконавчим органом;

в) мають повноваження щодо застосування норм адміністративного права та покарання за адміністративні порушення,

\section{Висновки}

Отже, з урахуванням зазначеного, можна зробити висновок, що виконавчі органи місцевих рад в Україні визнаються як нижчий рівень органів виконавчої влади, що є функціонально інтегрованими в їі систему. На місцевому рівні створюється комплексна система органів, що здійснюють функції виконавчої влади: система органів виконавчої влади та система виконавчих органів місцевих рад. При цьому залучення виконавчих органів місцевих рад в цю систему відбувається в залежності від галузі (сфери) діяльності. Такими галузями (сферами) діяльності на сьогоднішній день є: соціальноекономічний та культурний розвиток, планування та облік, бюджет, фінанси та ціни; управління комунальною власністю; житлово-комунальне господарство, побутове, торгівельне обслуговування; громадське харчування, транспорт та зв’язок; будівництво; освіта, охорона здоров'я, культура, фізкультура та спорт; регулювання земельних відносин і охорона навколишнього природного середовища; соціальний захист населення; зовнішньоекономічна діяльність; оборонна робота; забезпечення законності, правопорядку, охорона прав, свобод та законних інтересів громадян; відзначення державними нагородами.

А отже загалом, виконавчий комітет має дуже широкі повноваження. Чи є така потреба сьогодні? Однозначно - ні. Місцеві ради, як правило, мають компетентний депутатський корпус. Їх комісії спроможні кваліфіковано розглядати підготовлені виконавчими органами ради проекти рішень. Більше 
того, чинне законодавство розробило достатню кількість інструментів запобігання прийняттю незаконних рішень. А отже, вочевидь, час законодавчо поставити крапку в існуванні органів, необхідність існування яких під сумнівом від моменту утворення, що має знайти зміни в Законі України «Про місцеве самоврядування в Україні».

\section{Список використаної літератури}

1. Закон України «Про місцеве самоврядування в Україні»: режим доступу: https://zakon.rada.gov.ua/laws/show/280/97-\%D0\%B2\%D1\%80\#Text

2. Регламент роботи виконавчого комітету та виконавчих органів Луцької міської ради, затверджений рішенням виконавчого комітету міської рад від 17.02.2021 № 116-1 (зі зміною від 19.05.2021 № 374-1: режим доступу https://www.lutskrada.gov.ua/pages/rehlament-robotyvykonavchoho-komitetu-lutskoi-miskoi-rady/

3. РЕГЛАМЕНТ Луцької міської ради VIII скликання: режим доступу: https://www.lutskrada.gov.ua/pages/rehlament-roboty-vykonavchoho-komitetu-lutskoi-miskoi-rady.

4. Штирьов О. М. Взаємодія елементів системи місцевого самоврядування на муніципальному рівні: зарубіжний досвід та національні особливості. Наукові праці. Державне управління. 2014. Том 235. № 223. C. 133-138. URL: http://official.chdu.edu.ua/article/ view/28279/25204.

5. Регламент Львівської міської ради: режим доступу https://city-adm.lviv.ua/lmr/regulations-lmr.

1. Law of Ukraine on local self-government in Ukraine: access regime: https://zakon.rada.gov.ua/laws/show/280/97-\%D0\%B2\%D1\%80\#Text

2. Regulations of work of executive committee and executive bodies of the Lutsk city council, approved by the decision of executive committee of city councils from 17.02.2021 № 116-1 (with change from 19.05.2021 № 374-1: access regime https://www.lutskrada.gov.ua/pages/rehlament-roboty-vykonavchohokomitetu-lutskoi-miskoi-rady

3. REGULATIONS of the Lutsk City Council of the VIII convocation: access mode:

https://www.lutskrada.gov.ua/pages/rehlament-roboty-vykonavchoho-komitetu-lutskoi-miskoi-rady.

4. Shtyrev OM Interaction of elements of the system of local self-government at the municipal level:

foreign experience and national features. Scientific works. Governance. 2014. Volume 235. № 223. pp. 133-138. URL: http://official.chdu.edu.ua/article/ view / 28279/25204.

5. Regulations of the Lviv City Council: access regime https://city-adm.lviv.ua/lmr/regulations-lmr. 